\title{
Amphipod-based food web: Themisto gaudichaudii caught in nets and by seabirds in Kerguelen waters, southern Indian Ocean
}

\author{
Pierrick Bocher $^{1,2}$, Yves Cherel ${ }^{1, *}$, Jean-Philippe Labat ${ }^{3}$, Patrick Mayzaud ${ }^{3}$, \\ Suzanne Razouls ${ }^{4}$, Pierre Jouventin ${ }^{1,5}$ \\ ${ }^{1}$ Centre d'Etudes Biologiques de Chizé, UPR-CNRS 1934, 79360 Villiers-en-Bois, France \\ ${ }^{2}$ Laboratoire de Biologie et Environnement Marins, EA 1220 de l'Université de La Rochelle, 17026 La Rochelle Cedex, France \\ ${ }^{3}$ Laboratoire d'Océanographie Biochimique et d'Ecologie, ESA 7076-CNRS/UPMC LOBEPM, Observatoire Océanologique, \\ BP 28, 06230 Villefranche-sur-Mer, France \\ ${ }^{4}$ Observatoire Océanologique, UMR-CNRS/UPMC 7621, Laboratoire Arago, 66650 Banyuls-sur-Mer, France \\ ${ }^{5}$ Centre d'Ecologie Fonctionnelle et Evolutive, UPR-CNRS 9056, 1919 Route de Mende, 34293 Montpellier Cedex 5, France
}

\begin{abstract}
Comparing food samples from diving and surface-feeding seabirds breeding in the Golfe du Morbihan at Kerguelen Islands to concurrent net samples caught within the predator foraging range, we evaluated the functional importance of the hyperiid amphipod Themisto gaudichaudii in the subantarctic pelagic ecosystem during the summer months. T. gaudichaudii occurred in high densities (up to 61 individuals $\mathrm{m}^{-3}$ ) in the water column, being more abundant within islands in the western part of the gulf than at open gulf and shelf stations. The amphipod was a major prey of all seabird species investigated except the South Georgian diving petrel, accounting for 39, 80, 68, 59 and $46 \%$ of the total number of prey of blue petrels, thin-billed prions, Antarctic prions, common diving petrels and southern rockhopper penguins, respectively. The length-frequency distribution of $T$. gaudichaudii was similar between the 2 diving species, which fed on 1 large size class of adult individuals, whereas the 3 surface-feeding seabirds preyed upon 2 size classes but in different proportions. Juveniles and adults T. gaudichaudii were equally important in the diet of blue petrels, whereas juveniles and adults predominated in the food of thin-billed and Antarctic prions, respectively. Comparison of T. gaudichaudii found in nets and food samples together with observations at sea indicated that common diving petrels and southern rockhopper penguins fed in the close vicinity of the colonies in the Golfe du Morbihan, whereas blue petrels, and thin-billed and Antarctic prions mainly preyed upon amphipods outside the sampled area. Our study shows that T. gaudichaudii is an important local component of the macrozooplankton community and the main prey for planktivorous seabirds inhabiting the Kerguelen archipelago. In certain areas of the subantarctic zone, it therefore has a trophic role similar to that of Antarctic krill Euphausia superba further south, in Antarctic waters.
\end{abstract}

KEY WORDS: Antarctica · Euphausia superba $\cdot$ Pelagic ecosystem $\cdot$ Penguins $\cdot$ Petrels $\cdot$ Prions · Top predators $\cdot$ Trophic web

\section{INTRODUCTION}

The genus Themisto is one of the largest genera of the pelagic amphipod family Hyperiidae. Two species of the genus occur in the Southern Ocean, T. australis and T. gaudichaudii (de Broyer \& Jazdzewski 1993,
Vinogradov et al. 1996), the latter being one of the numerous species of macrozooplankton in the epipelagic zone (Kane 1966, Everson \& Ward 1980, Pakhomov \& McQuaid 1996). T. gaudichaudii is a non-selective, opportunistic predator which feeds on the most abundant prey (Pakhomov \& Perissinotto 1996, Froneman et al. 
2000). It was estimated that the species can control the mesozooplankton community through its predation impact and may thus significantly contribute to downward flux of biogenic carbon (Pakhomov \& Perissinotto 1996). It may also act as a direct link between mesozooplankton and higher levels of the trophic web, since T. gaudichaudii is consumed by a variety of top predators, including fish (Kock et al. 1994), squid (Ivanovic \& Brunetti 1994), and air-breathing vertebrates (Budylenko 1978, Cooper \& Brown 1990, Ridoux 1994). To our
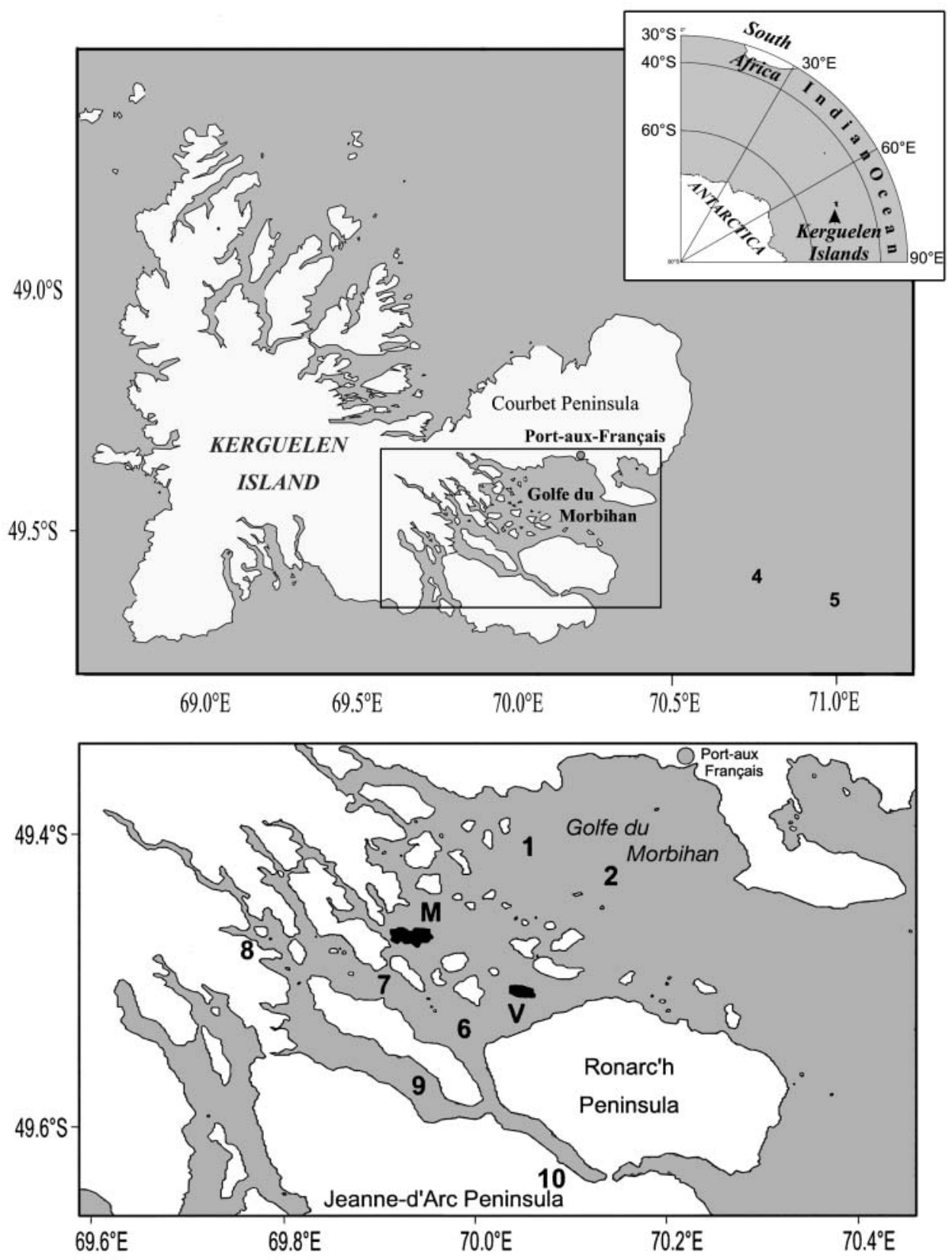

Fig. 1. Themisto gaudichaudii. Map of Kerguelen Islands (upper panel) and details of the eastern part of the archipelago (lower panel). Numbers 1 to 10: locations of macrozoplanktonic stations (note that there is no Station 3), M: Ile Mayes; V: IleVerte knowledge, however, no attempt was made at a given locality to sample $T$. gaudichaudii in the macrozooplankton community and in the diet of several predators at the same time, in order to assess first its numerical and biomass importance in the pelagic ecosystem and in seabird nutrition, and second prey-predator relationships between $T$. gaudichaudii and the community of planktivorous seabirds.

The Kerguelen Islands lie in the southern part of the Polar Frontal Zone, in the immediate vicinity of the Antarctic Polar Front (Park \& Gambéroni 1997). There, macrozooplankton crustaceans are dominated by Euphausia vallentini, Thysanoessa spp. and Themisto gaudichaudii. Antarctic krill E. superba is not found in the area (Pakhomov 1993). Thirty-five bird species breed on the archipelago, where the avian community (6.5 to 10.9 million annual breeding pairs) is dominated by small Procellariiformes and crested penguins (Weimerskirch et al. 1989), which are known to mainly prey on zooplankton elsewhere (Marchant \& Higgins 1990). Almost nothing is known about the diets of seabirds at Kerguelen Islands, but preliminary studies together with an exploratory field work during the 1993-1994 austral summer suggested that unidentified amphipods or T. gaudichaudii account for a significant part of their food (Falla 1937, Paulian 1953, Bost et al. 1994, Chaurand \& Weimerskirch 1994, authors' unpubl. data). An integrative scientific programm (IOZ: Interactions Oiseaux-Zooplancton) was therefore conducted to sample the macrozooplankton community in the vicinity of predator breeding sites and to collect food samples from seabird species during the summer months. The seabirds were 5 small burrowing petrels (blue petrel Halobaena caerulea, thin-billed Pachyptila belcheri and Antarctic P. desolata prions, and South Georgian Pelecanoides georgicus and common P. urinatrix diving petrels) and the south- 
ern rockhopper penguin (Eudyptes chrysocome filholi). They account for about $67 \%$ of the total number of birds of the archipelago (Weimerskirch et al. 1989) and it was estimated that the 6 species together consume annually more than 0.6 million $\mathrm{t}$ of marine resources (Guinet et al. 1996).

The main objectives of the present study were first to quantify the abundance and size classes of Themisto gaudichaudii in net samples performed in a coastal area (Golfe du Morbihan) and in more offshore waters during the summer months (the chick-rearing period of seabirds). Second, we quantified abundance and size classes of $T$. gaudichaudii in the diet of a community of planktivorous predators including both surface-feeding (blue petrels and prions) and diving (diving petrels and rockhopper penguins) birds. Finally, we compared the characteristics of $T$. gaudichaudii eaten by the different species of seabirds with those found in macrozooplankton samples to gain further information on dietary segregation, including foraging areas, of seabirds.

\section{METHODS}

Study site and macrozooplankton sampling. Fieldwork was carried out at Iles Kerguelen, southern
Indian Ocean (Fig. 1). Macrozooplankton was sampled inside and outside the Golfe du Morbihan in 3 groups of stations with different bathymetric and hydrological characteristics. The Golfe du Morbihan is a large gulf (about $700 \mathrm{~km}^{2}$ ) located in the eastern part of the archipelago. The first group of stations (open gulf, Stns 1 and 2) was located in the northern part of the bay, which is free of islands, has maximum depths of $60 \mathrm{~m}$, and opens to the Indian Ocean through the Passe Royale, which is $12 \mathrm{~km}$ wide and about $40 \mathrm{~m}$ deep. The second group (shelf, Stns 4 and 5) was located in open ocean, Stn 4 over the periinsular shelf in neritic waters, and Stn 5 over the upper slope, in $500 \mathrm{~m}$ deep waters. The third group (western gulf, Stns 6 to 10) was located around Ile Longue in the south-western part of the Golfe du Morbihan, which is characterised by deep submarine valleys (to $220 \mathrm{~m}$ depth) and numerous islands and islets (Fig. 1).

Macrozooplankton sampling was carried out between 14 January and 17 February 1996 (Table 1), thus encompassing the study periods of all seabird species, except for the Antarctic prion (Table 2). Bad weather precluded sampling several times at the shelf stations, Stn 4 being sampled only once and Stn 5 not being sampled in February. Macrozooplankton was collected

Table 1. Themisto gaudichaudii. Description of the stations sampled and characteristics of T. gaudichaudii collected at these stations in summer 1996 at Kerguelen Islands. DW: dry weight

\begin{tabular}{|c|c|c|c|c|c|c|c|c|c|c|}
\hline & \multicolumn{4}{|c|}{ Stations } & \multicolumn{6}{|c|}{ Themisto gaudichaudii } \\
\hline & & $\begin{array}{l}\text { Date } \\
(\mathrm{d} / \mathrm{mo})\end{array}$ & $\begin{array}{l}\text { Depth } \\
\text { filtered } \\
\text { (m) }\end{array}$ & $\begin{array}{c}\text { Volume } \\
\text { filtered } \\
\left(\mathrm{m}^{3}\right)\end{array}$ & $\begin{array}{l}\text { Number of } \\
\text { individuals }\end{array}$ & $\begin{array}{l}\text { Density } \\
\left(\mathrm{n} \mathrm{m}^{-3}\right)\end{array}$ & $\begin{array}{l}\text { Biomass } \\
\text { DW } \\
\left(\mathrm{mg} \mathrm{m}^{-3}\right)\end{array}$ & $\begin{array}{c}\text { Relative } \\
\text { biomass DW } \\
(\%)\end{array}$ & $\begin{array}{l}\text { Mean body } \\
\text { length } \\
(\mathrm{mm})\end{array}$ & $\begin{array}{c}\text { Sex ratio }^{a} \\
(\mathrm{f} / \mathrm{f}+\mathrm{m})\end{array}$ \\
\hline Open gulf stations & $\begin{array}{l}1 \\
2 \mathrm{~A} \\
2 \mathrm{~B}\end{array}$ & $\begin{array}{l}11 / 02 \\
01 / 02 \\
11 / 02\end{array}$ & $\begin{array}{l}0-30 \\
0-60 \\
0-60\end{array}$ & $\begin{array}{r}687 \\
1193 \\
1041\end{array}$ & $\begin{array}{r}506 \\
2804 \\
4992\end{array}$ & $\begin{array}{l}0.7 \\
2.4 \\
4.8\end{array}$ & $\begin{array}{r}3.9 \\
11.3 \\
24.8\end{array}$ & $\begin{array}{l}99.2 \\
97.0 \\
99.5\end{array}$ & $\begin{array}{r}7.5 \\
8.5 \\
11.1\end{array}$ & $\begin{array}{l}0.79^{* * *} \\
0.76^{* * *} \\
0.89^{* * *}\end{array}$ \\
\hline Shelf stations & $\begin{array}{l}4 \\
5 \mathrm{~A} \\
5 \mathrm{~B}\end{array}$ & $\begin{array}{l}01 / 02 \\
14 / 01 \\
31 / 01\end{array}$ & $\begin{array}{l}0-100 \\
0-200 \\
0-200\end{array}$ & $\begin{array}{l}1818 \\
2536 \\
3992\end{array}$ & $\begin{array}{r}235 \\
1184 \\
219\end{array}$ & $\begin{array}{l}0.1 \\
0.5 \\
0.1\end{array}$ & $\begin{array}{l}1.3 \\
1.1 \\
0.1\end{array}$ & $\begin{array}{r}84.6 \\
15.6 \\
2.7\end{array}$ & $\begin{array}{r}12.9 \\
9.9 \\
10.6\end{array}$ & $\begin{array}{l}0.84^{* * *} \\
0.94^{* * *} \\
0.86^{* * *}\end{array}$ \\
\hline Western gulf stations & $\begin{array}{l}6 \mathrm{~A} \\
6 \mathrm{~B} \\
6 \mathrm{C}\end{array}$ & $\begin{array}{l}24 / 01 \\
06 / 02 \\
17 / 02\end{array}$ & $\begin{array}{l}0-140 \\
0-140 \\
0-140\end{array}$ & $\begin{array}{r}666 \\
1418 \\
1795\end{array}$ & $\begin{array}{r}1752 \\
4501 \\
14920\end{array}$ & $\begin{array}{l}2.6 \\
3.2 \\
8.3\end{array}$ & $\begin{array}{l}27.3 \\
24.5 \\
44.2\end{array}$ & $\begin{array}{l}10.7 \\
19.2 \\
35.6\end{array}$ & $\begin{array}{l}14.3 \\
12.5 \\
12.4\end{array}$ & $\begin{array}{l}0.80^{* * *} \\
0.53^{n s} \\
0.70^{* * *}\end{array}$ \\
\hline & $\begin{array}{l}7 \mathrm{~A} \\
7 \mathrm{~B} \\
7 \mathrm{C}\end{array}$ & $\begin{array}{l}24 / 01 \\
06 / 02 \\
17 / 02\end{array}$ & $\begin{array}{l}0-100 \\
0-100 \\
0-100\end{array}$ & $\begin{array}{l}1373 \\
1424 \\
1131\end{array}$ & $\begin{array}{r}4208 \\
6160 \\
11672\end{array}$ & $\begin{array}{r}3.1 \\
4.3 \\
10.3\end{array}$ & $\begin{array}{l}11.7 \\
11.0 \\
84.3\end{array}$ & $\begin{array}{l}30.2 \\
12.2 \\
83.4\end{array}$ & $\begin{array}{r}7.6 \\
8.8 \\
13.0\end{array}$ & $\begin{array}{l}0.76^{* * *} \\
0.68^{* * *} \\
0.62^{* * *}\end{array}$ \\
\hline & $\begin{array}{l}8 \mathrm{~A} \\
8 \mathrm{~B} \\
8 \mathrm{C}\end{array}$ & $\begin{array}{l}24 / 01 \\
06 / 02 \\
17 / 02\end{array}$ & $\begin{array}{l}0-60 \\
0-60 \\
0-60\end{array}$ & $\begin{array}{l}855 \\
544 \\
396\end{array}$ & $\begin{array}{l}13792 \\
23520 \\
24032\end{array}$ & $\begin{array}{l}16.1 \\
43.2 \\
60.7\end{array}$ & $\begin{array}{r}54.6 \\
30.5 \\
232.7\end{array}$ & $\begin{array}{l}96.8 \\
92.1 \\
98.0\end{array}$ & $\begin{array}{l}12.7 \\
13.2 \\
13.0\end{array}$ & $\begin{array}{l}0.78^{* * *} \\
0.67^{* * *} \\
0.62^{* * *}\end{array}$ \\
\hline & $\begin{array}{l}9 \mathrm{~A} \\
9 \mathrm{~B} \\
9 \mathrm{C}\end{array}$ & $\begin{array}{l}24 / 01 \\
06 / 02 \\
17 / 02\end{array}$ & $\begin{array}{l}0-100 \\
0-100 \\
0-100\end{array}$ & $\begin{array}{l}1536 \\
1251 \\
1226\end{array}$ & $\begin{array}{l}4912 \\
2416 \\
8504\end{array}$ & $\begin{array}{l}3.2 \\
1.9 \\
6.9\end{array}$ & $\begin{array}{r}7.9 \\
30.0 \\
39.0\end{array}$ & $\begin{array}{l}34.5 \\
30.5 \\
62.1\end{array}$ & $\begin{array}{l}14.5 \\
15.0 \\
13.6\end{array}$ & $\begin{array}{l}0.77^{* * *} \\
0.62^{* * *} \\
0.64^{* * *}\end{array}$ \\
\hline & $\begin{array}{l}10 \mathrm{~A} \\
10 \mathrm{~B} \\
10 \mathrm{C}\end{array}$ & $\begin{array}{l}24 / 01 \\
06 / 02 \\
17 / 02\end{array}$ & $\begin{array}{l}0-100 \\
0-100 \\
0-100\end{array}$ & $\begin{array}{r}1695 \\
1202 \\
720\end{array}$ & $\begin{array}{r}2928 \\
10208 \\
12448\end{array}$ & $\begin{array}{r}1.7 \\
8.5 \\
17.3\end{array}$ & $\begin{array}{r}32.8 \\
61.4 \\
115.6\end{array}$ & $\begin{array}{l}94.2 \\
95.9 \\
98.4\end{array}$ & $\begin{array}{l}15.0 \\
15.2 \\
15.6\end{array}$ & $\begin{array}{l}0.64^{* * *} \\
0.62^{* * *} \\
0.60^{* * *}\end{array}$ \\
\hline
\end{tabular}




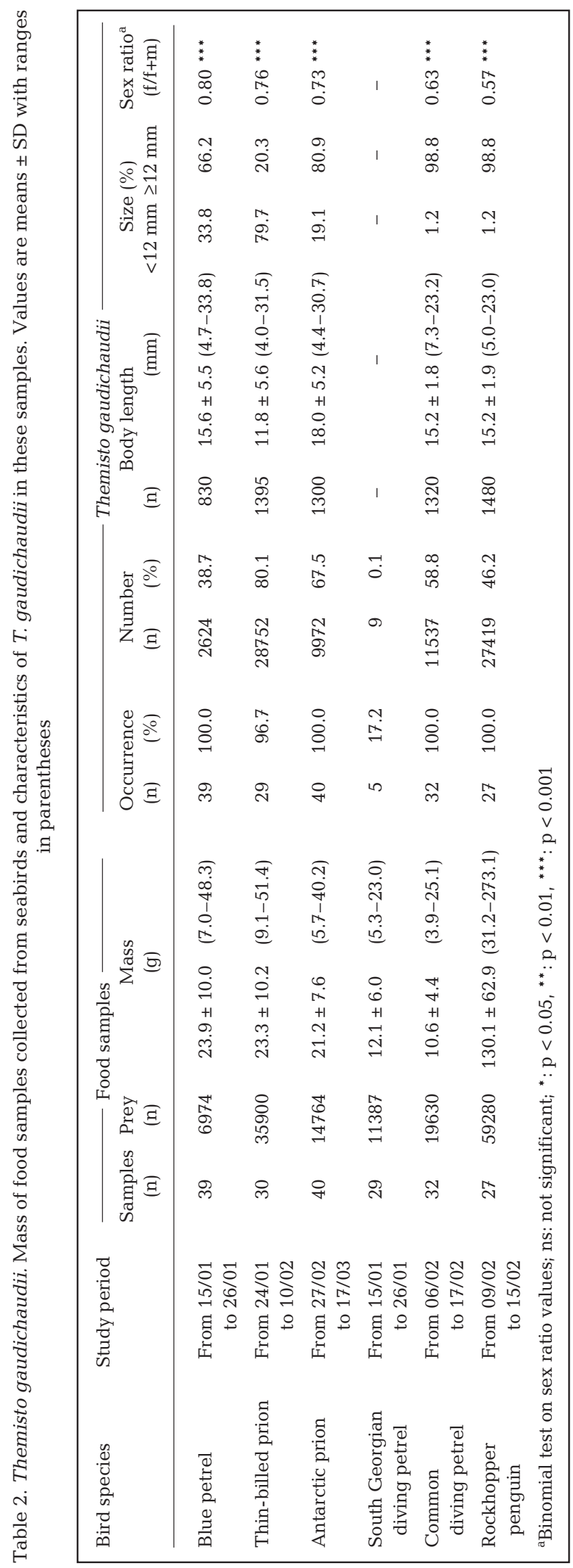

at night by oblique hauls (bottom to surface, and $200 \mathrm{~m}$ to surface at the deeper Stn 5) using an ORI net (2 $\mathrm{m}^{2}$; $1 \mathrm{~mm}$ mesh) (Omori \& Ikeda 1984). Two consecutive samplings were performed at each station. Both samples were preserved aboard, either in a $5 \%$ buffered formalin-water solution or in seawater. At the shorebased laboratory, seawater samples were sorted out, rinsed with $4.5 \%$ ammonium formate and dried for $2 \mathrm{~d}$ at $60^{\circ} \mathrm{C}$ for later biomass measurements (mg dry weight $\mathrm{m}^{-3}$ ) in order to quantify the absolute and relative importance of Themisto gaudichaudii in the macrozooplanktonic community. Formalin samples were sent to Villefranche-sur-Mer, France, for species identification and counting in sub-samples using the Motoda box technique (Omori \& Ikeda 1984).

Birds and dietary analyses. Study colonies of birds were located in 2 adjacent islands of the Golfe du Morbihan (Fig. 1), where large populations of petrels and a smaller population of rockhopper penguins breed (Weimerskirch et al. 1989). Blue petrels (BP), thin-billed prions (TBP), common diving petrels (CDP) and southern rockhopper penguins (SRP) were studied on Ile Mayes $\left(49^{\circ} 28^{\prime} \mathrm{S}, 69^{\circ} 57^{\prime} \mathrm{E}\right)$, and South Georgian diving petrels (SGDP) and Antarctic prions (AP) on Ile Verte $\left(49^{\circ} 31^{\prime} \mathrm{S}, 70^{\circ} 04^{\prime} \mathrm{E}\right)$. Each species was studied for between 7 and 20 consecutive days, which corresponds roughly to the middle of the chick-rearing period. Because breeding cycles are not synchronised between species (Weimerskirch et al. 1989), the timing of the study periods varied according to the species, the whole study period occurring between 15 January and 17 March (Table 2).

Breeding petrels and prions were caught at night by mist netting or in burrows fitted with trap doors at the entrance to retain the adult before the chick was fed. Breeding adult SRP were captured in late afternoon when they came ashore to feed their chicks. Food samples from BP, TBP and AP were collected by spontaneous regurgitation, and those from CDP, SGDP and SRP by stomach lavage following Gales (1987) and Bocher et al. (2000a). Birds were flushed 1 to 3 times. No individual bird was sampled more than once. Samples collected by flushing were then drained to remove excess water.

All the samples were immediately frozen at $-20^{\circ} \mathrm{C}$ and returned to Chizé, France, for analysis. In the laboratory, each sample was thawed, drained, weighed and placed in a flat-bottomed tray. Fresh remains were divided into broad prey classes (crustaceans, fish and other organisms), which were weighed to estimate their proportions by fresh mass in the diet. Total numbers of common and rare prey items were counted in each individual sample. Prey were identified using published keys and by comparison with material held in our own reference collection. All individuals of the 
amphipod Themisto gaudichaudii were sorted and determined following Vinogradov et al. (1996); they were then sexed and measured (see below). The importance of $T$. gaudichaudii in the diet of each seabird species was assessed by calculating its frequency of occurrence (number of samples containing T. gaudichaudii as a percent of total number of samples) and its percentage by number (number of $T$. gaudichaudii as a percent of total number of prey in the pooled samples).

Length measurements and sex determination of Themisto gaudichaudii. A randomly selected subsample of $T$. gaudichaudii was measured from each macrozooplankton sample ( $\mathrm{n}=150$ to 200 specimens), and from each food sample ( $\mathrm{n}=30$ to 60 ) containing more than 30 measurable individuals. All T. gaudichaudii length measurements are given as the total body length (BL). For net-caught individuals and intact individuals from seabird diet, these were measured directly from the front of the eye to the tip of the uropods; whereas those from digested specimens from food samples were estimated from eye height $(E H)$, using the following allometric equation:

$$
\begin{gathered}
\mathrm{BL}=(6.61 \times \mathrm{EH})-0.71, \mathrm{r}=0.97, \mathrm{n}=1005 \\
\text { range: } 4 \text { to } 30 \mathrm{~mm} \mathrm{BL}
\end{gathered}
$$

Length-frequency distributions are presented at $1 \mathrm{~mm}$ length classes. For each net sample and each food sample, we calculated first the absolute lengthfrequency distribution from the measured individuals only, and second, the relative length-frequency distribution for the whole sample by multiplying the number of individuals in each $1 \mathrm{~mm}$ size class by the ratio total number of $T$. gaudichaudii/number of measured individuals, multiplied by 100 . Data from the same macrozooplanktonic station performed at different dates and those from food samples for a given seabird species were pooled by adding together the number of T. gaudichaudii of the same size class from all the samples, and adding the numbers of individuals in all size classes to calculate the total number of $T$. gaudichaudii.

Small Themisto gaudichaudii $(\mathrm{BL}<12 \mathrm{~mm})$ were not sexed, but sexes of larger individuals (BL $\geq 12 \mathrm{~mm}$ ) were determined by the use of secondary sexual characters. Males were identified by the flagellum of the second antennae, which become divided into many segments and filaments, whereas they remain short and unsegmented in the females (Kane 1963).

Data analysis. A correspondence analysis, or CA (Benzecri 1973) was used to analyse the size structure data of Themisto gaudichaudii. CA is an ordination method (also called inertia method) which has been widely used in the analysis of ecological data (Gower 1987). Ordination methods were designed to show the main features of multivariate samples in a limiteddimension space. These dimensions (or axes) are the best summary of the information contained in the data. CA uses an ordination table as data, which provides a simultaneous representation of the individuals (rows) and descriptors (column) in the new space. CA was first designed for categorical descriptors, but can also be used to describe size structures (Badia \& Do-Chi 1976). Using chi-squared distances, CA compares the distribution of the sample profiles to that of the size class frequencies.

The present data set was composed of active (data used to compute the factorial axis) and illustrative individuals (data projected in the new space to illustrate relationships between data; they are not used to compute the factorial axis). Each individual was represented by size class distributions. The factorial axes of the CA were computed using active observations whereas illustrative or supplementary data were simply projected into this reference system without participating in its computation. In our study, the active observations were the Themisto gaudichaudii size structure in food samples for 132 birds belonging to 5 species (15 for BP, 23 for TBP, 36 for AP, 32 for CDP and 26 for SRP). Only food samples containing at least 30 measured individuals of $T$. gaudichaudii were used in CA representation. Supplementary data comprised the 21 size structures for the 9 macrozooplanktonic stations sampled at different times. The active individuals (birds), illustrative individuals (stations) and the descriptors (size classes) were represented in the same reference system. For each individual or descriptor, the quality of the representation is given by the part of the initial inertia projected in the new space used; the value, so-called relative contribution, varied between 0 and 1 .

Software. Data were analysed statistically using SYSTAT 9 for WINDOWS (Wilkinson 1999), and SPAD 3.01 for multivariate analysis. Values are means $\pm \mathrm{SD}$, significance at 0.05 level.

\section{RESULTS}

\section{Themisto gaudichaudii from macrozooplankton net samples}

The hyperiid amphipod Themisto gaudichaudii was found in all the 21 net hauls performed in Kerguelen waters during the summer months (Table 1). The species often occurred in high densities ( $>1$ individual $\mathrm{m}^{-3}$ in 17 stations, up to 61 individuals $\mathrm{m}^{-3}$ ) and biomasses ( $>10 \mathrm{mg}$ dry weight $\mathrm{m}^{-3}$ in 16 stations, up to $233 \mathrm{mg}$ $\mathrm{m}^{-3}$ ), being the dominant macrozooplanktonic species in a majority of hauls. Large temporal and spatial variations were found between and within stations. Tem- 
poral variations were observed at a given station with a tendency for density and biomass to increase over the study period. In a few stations, we found a nonconstant relationship between densities and biomasses calculated from the 2 successive hauls performed within a few minutes on the same day (see 'Methods'). The most likely explanation was the swarming behaviour of the genus Themisto (Gray \& McHardy 1967, Vinogradov et al. 1996) that may induce differences in the amount of individuals collected in net samples.

Overall, highest densities and biomasses of Themisto gaudichaudii were found in the western gulf stations, and by far the lowest values at the 2 shelf stations (Kruskal-Wallis for the 3 groups of stations, $H=9.27$ and 10.19, $\mathrm{p}=0.010$ and 0.006 for densities and bio- masses, respectively). In the latter, T. gaudichaudii was the main macrozooplanktonic species at Stn 4, but copepods (mainly Rhincalanus gigas) and euphausiids dominated by mass at the more offshore Stn 5. In open gulf stations (Stns 1 and 2), densities and biomasses were intermediate between those from shelf and western gulf stations. At Stns 1 and 2, T. gaudichaudii greatly predominated, accounting for more than $97 \%$ of the biomass (Table 1). Macrozooplankton, including mainly T. gaudichaudii and the carnivorous copepod Paraeuchaeta antarctica, reached its highest densities and biomasses in western gulf stations. T. gaudichaudii was the main species ( $>92 \%$ of the biomass) at Stns 8 and 10 located at the 2 extremities of the Golfe du Morbihan, whereas it co-occurred with P. antarctica at Stns 6, 7 and 9 located in more open waters within islands (Table 1, Fig. 1).

Fig. 2 illustrates length-frequency distributions of Themisto gaudichaudii at the different stations sampled in summer 1996. Lengthfrequency distributions were fairly consistent among the western gulf stations. All but Stn 8 showed either a bimodal distribution with a mode of juveniles at about 5 to $6 \mathrm{~mm}$ and a mode of adults at about 15 to $16 \mathrm{~mm}$ (Stns 6, 7 and 9), or an unimodal distribution with only the larger mode being present (Stn 10). Data from the 4 stations were therefore pooled to illustrate the bimodality of the length-frequency distribution in the western gulf. Note that only a few individuals larger than $20 \mathrm{~mm}$ BL $(0.3 \%$ of the total number of $T$. gaudichaudii) were caught in nets hauled in the western gulf (Fig. 2). Length-frequency distribution in open gulf and shelf stations were different from those in western gulf stations. A bimodal distribution occurred at Stn 1 with modes at 6 to $7 \mathrm{~mm}$ and 12 to $13 \mathrm{~mm}$, while no well-defined modes were found at Stns 2, 4 and 5. Lengthfrequency distributions were skewed towards larger size classes in Stns 2 and 4 and skewed towards small and medium size classes in Stn 5 (Fig. 2).

In all but one station, females Themisto gaudichaudii outnum-
Fig. 2. Themisto gaudichaudii. Length-frequency distribution in net hauls and in the diet of seabirds. Western gulf stations: pooled results from Stns 6, 7, 9 and 10; BP: blue petrel $_{i}$ TBP: thin-billed prion; AP: Antarctic prion; CDP: common diving petrel; SRP: southern rockhopper penguin. $\mathrm{N}$ : number of net hauls or food samples; $\mathrm{n}$ : number of individuals 
bered males within the sub-population of large individuals ( $\mathrm{BL} \geq 12 \mathrm{~mm}$ ) (Table 1). Sex ratio was nevertheless lower in western gulf stations (range: 0.53 to 0.80 , mean value: 0.67 ) than in open gulf stations (range: 0.76 to 0.89 , mean value: 0.81 ) and shelf stations (range: 0.84 to 0.94 , mean value: 0.88 ) (Kruskal-Wallis for the 3 groups of stations, $H=10.41$, $\mathrm{p}=0.005)$.

\section{Themisto gaudichaudii from seabird dietary samples}

A total of 197 food samples was collected and analysed to determine the dietary habits of the 6 seabird species ( $\mathrm{n}=27$ to 39 samples per species) in summer 1996 (Table 2). Food mass was different among the species (1-way ANOVA, $F_{5,191}=99.07, \mathrm{p}<$ 0.0001). Samples from southern rockhopper penguins (SRP) were much heavier than those from petrels and prions, and those from surface-feeding petrels and prions heavier than those from diving petrels. No significant differences were however found between the samples from blue petrels (BP), thin-billed prions (TBP) and Antarctic prions (AP) $\left(F_{2,106}=0.928, \mathrm{p}=0.398\right)$, and between those from South Georgian diving petrels (SGDP) and common diving petrels (CDP) $\left(F_{1,59}=1.28\right.$, $\mathrm{p}=0.263$ ).

Crustaceans were important prey items for all the seabird species (Fig. 3). They co-occurred with fish as the main prey of BP and SRP (52\% and $49 \%$ by fresh mass, respectively), and they dominated in the food of TBP ( $97 \%$ by fresh mass), AP $(87 \%)$, SGDP $(97 \%)$ and CDP $(100 \%)$. Squid, polychaetes and gelatinous plankton were only minor components of the diet.

Themisto gaudichaudii was a major prey item for all seabird species except the SGDP (Table 2). In the latter species, it was found in only $17 \%$ of the samples and was negligible by number. Data from SGDP were therefore not considered further in the present work, the species preying mainly on the euphausiid Thysanoessa sp. and the copepod Calanoides acutus. Excluding the SGDP, T. gaudichaudii occurred in almost all the food samples. Overall, a total of $80304 T$. gaudichaudii was counted in stomach contents of the remaining 5 seabird species. Percentages by number of $T$. gaudichaudii were significantly different among avian predators (Pearson chi-squared test, $\chi_{4}^{2}=$ $26642.23, \mathrm{p}<0.0001$ ), ranging from $39 \%$ (BP) to $80 \%$ (TBP) (Table 2). It was by far the major item of AP, TBP and CDP, and it co-occurred with Thysanoessa sp. as the main prey item in the diet of $\mathrm{BP}$, and with the euphausiid Euphausia vallentini, the copepod Paraeuchaeta antarctica and fish postlarvae in the diet of SRP.

Mean body length of Themisto gaudichaudii varied significantly in seabird diets (several T. gaudichaudii measurements having been made for a given food sample, a nested ANOVA was performed and the $F$ value of bird species was constructed with the mean square of individuals nested within species as the error term; $F_{4,127}=21.66, \mathrm{p}<0.0001$ ) (Table 2). All the values were significantly different (post hoc Tukey HSD multiple comparison test, all $p<0.0001$ ), except those for BP and for the 2 diving species CDP and SRP ( $p>0.934)$. Accordingly, the length-frequency distributions of $T$. gaudichaudii were similar for CDP and SRP, both species feeding on 1 size class with a mode at 15 to $16 \mathrm{~mm}$ BL (Fig. 2). The situation is more complex in surface-feeding seabirds. The 2 species of prions and BP preyed upon 2 size classes, but in different proportions. Juveniles (mode at 9 to $10 \mathrm{~mm}$ ) and adults (mode at 18 to $19 \mathrm{~mm}$ ) T. gaudichaudii were equally important in the diet of BP, whereas juveniles (mode at 8 to $9 \mathrm{~mm}$ ) predominated over adults (mode at 16 to $17 \mathrm{~mm}$ ) for TBP, and adults (mode at 19 to $20 \mathrm{~mm}$ ) predominated over juveniles (mode at 7 to $8 \mathrm{~mm}$ ) for AP. Large individuals (BL $>20 \mathrm{~mm}$ ) accounted for a significant proportion of $\mathrm{T}$. gaudichaudii eaten by surface-feeding seabirds (BP: $11.7 \%$, TBP: $3.8 \%$, AP: $30.9 \%$ ), but for a smaller proportion of those found in the diet of diving birds (CDP: 0.9\%, SRP: 0.9\%).

In food samples of all seabird species, females Themisto gaudichaudii outnumbered males within the sub-population of large individuals (BL $\geq 12 \mathrm{~mm}$ )

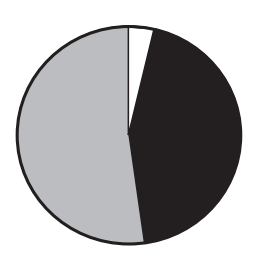

$\mathrm{BP}$

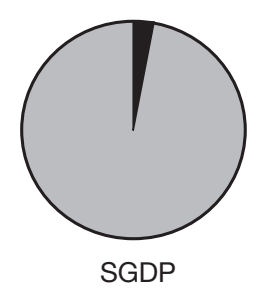

Crustaceans

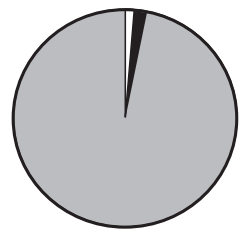

TBP

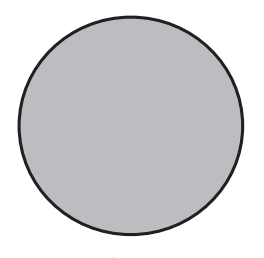

CDP

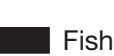

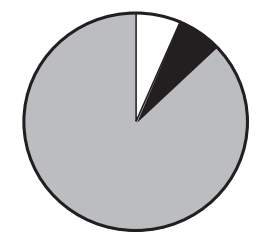

AP

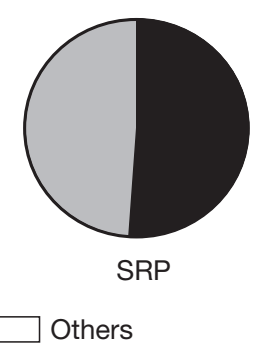

Fig. 3. Themisto gaudichaudii. Composition by fresh mass of the diet of seabirds in the 1996 summer months. BP: blue petrel; TBP: thin-billed prion; AP: Antarctic prion; SGDP: South Georgian diving petrel; CDP: common diving petrel, SRP: southern rockhopper penguin 

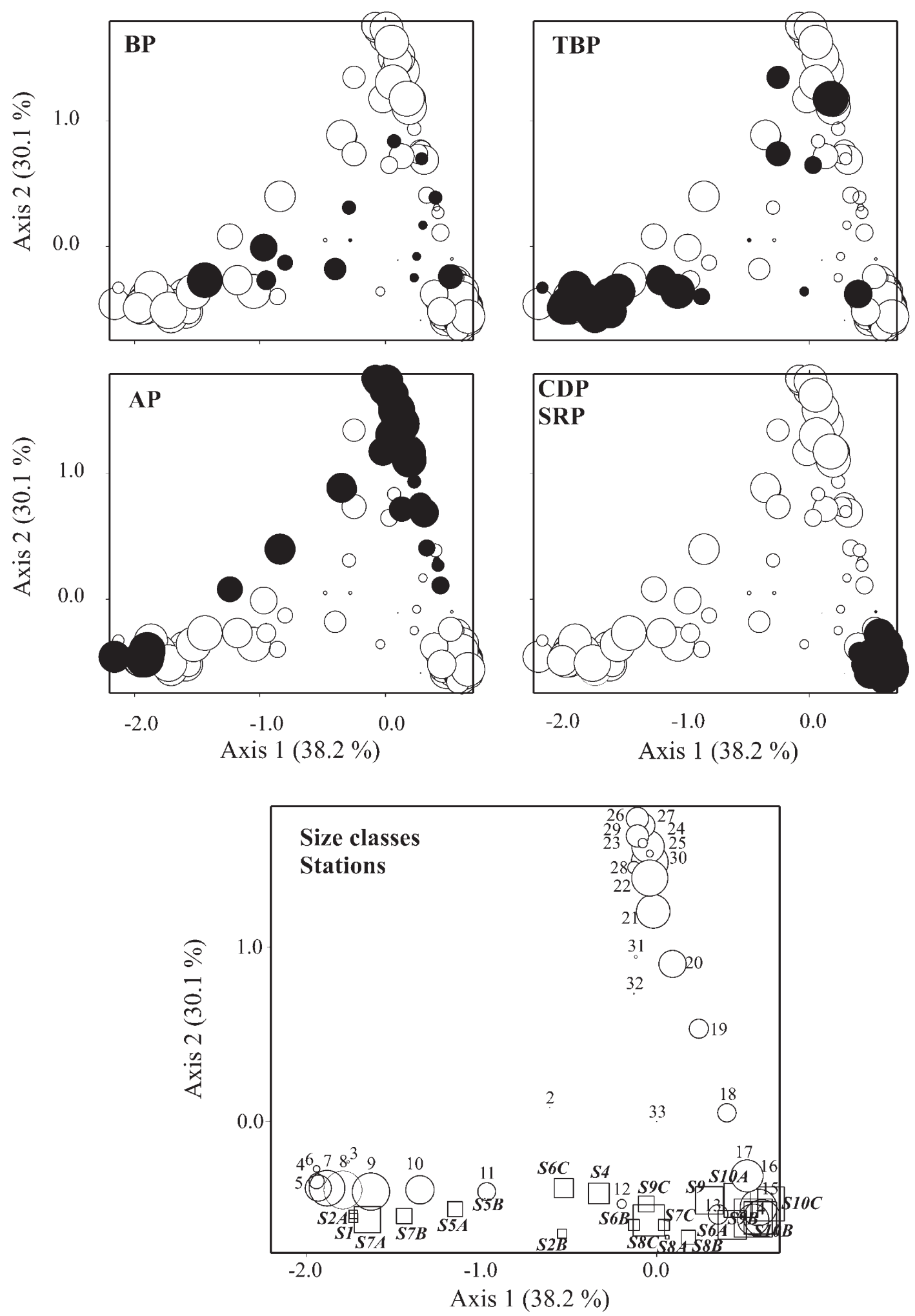

Fig. 4. Themisto gaudichaudii. Plan of the axes 1 and 2 of the correspondence analysis of the size classes in the diet of seabirds (4 upper panels) and net hauls (lower panel). Bird species, net hauls and size classes are presented in different graphics to avoid overloading the representation, but the space is identical. The symbol for each object is proportional to its relative contribution, an index of the quality of the representation. BP: blue petrel; TBP: thin-billed prion; AP: Antarctic prion; CDP: common diving petrel; SRP: southern rockhopper penguin; N: number of net hauls or food samples; n: number of individuals 
(Table 2). Sex ratio was higher in surface-feeding seabirds than in diving species (mean values: 76.1 and $59.3 \%$, respectively, $\left.\chi^{2}=102.98, p<0.0001\right)$. It was also significantly different, but at a lower level, when comparing BP, TBP and AP $\left(\chi_{2}^{2}=6.37, \mathrm{p}=0.041\right)$, and when comparing $\operatorname{CDP}$ and $\operatorname{SRP}\left(\chi^{2}=8.77, \mathrm{p}=0.003\right)$.

\section{Themisto gaudichaudii from seabirds and nets: similarities and differences}

A comparison of length frequency distribution of Themisto gaudichaudii between macrozooplankton samples and dietary samples indicated large differences (Kolmogorov-Smirnov, all p < 0.0001) (Fig. 2). Both juveniles and adults were found in most net hauls and food samples, but both their proportion and modes showed large variations. Noticeable was the near lack of large individuals (BL > $20 \mathrm{~mm}$ ) in macrozooplankton samples and in food samples from diving birds, whereas they accounted for a significant proportion of the amphipods in the diet of surface-feeding seabirds. The only similarity was found between the size class of $T$. gaudichaudii eaten by CDP and SRP that was identical to the largest size class occurring in most of the western gulf stations (Fig. 2). Because pooling data for a given bird species did not describe differences occurring between individual food samples (= individual birds), we used frequency-distribution of T. gaudichaudii from 132 dietary samples from 5 seabird species to calculate a correspondence analysis (see 'Methods'), and to compare it with the macrozooplanktonic samples (Fig. 4).

Axes 1 and 2 represented 38.2 and $30.1 \%$ of the inertia, respectively. The third axis represented only $8.6 \%$ of the inertia and consequently could be ignored, as other following axes. The size classes were regularly distributed on the plane defined by axes 1 and 2. Axis 1 opposed the smallest to the medium sizes of Themisto gaudichaudii, and axis 2 opposed the previous 2 size classes to the largest one. Macrozooplanktonic stations, projected as illustrative data, were distributed solely along the first axis. Stns 1, 2 and 5 were linked with the smaller sizes, Stns 8, 9,10 were associated with the medium size classes, and Stns 6 and 7 were more variable (Fig. 4). The relative contribution between stations and reference plane were indicative of a good match between size structure at each station and size structure in the food samples.

The size structures of Themisto gaudichaudii recorded in the food samples from BP did not match the description made for other bird species. The size structure pattern was without correspondence with other individual birds or stations, except maybe 1 BP feeding on the larger size class occurring in the western gulf (Fig. 4).

The majority of TBP samples was located in the area associated with the smaller Themisto gaudichaudii size classes, some of them being close to those found at open gulf stations and the western gulf Stn 7. Four individual birds displayed a prey size structure linked with the large size not found in the Golfe du Morbihan. Unlike TBP samples, the majority of AP samples were located in the same area of the 1-2 plane when compared to the larger size classes of T. gaudichaudii (21 to $30 \mathrm{~mm}$ ). None of the stations showed an association with this part of the plane, because such large size classes were never found in net samples except for odd individuals at Stn 5. Nevertheless, a few AP samples showed an association with $T$. gaudichaudii of smaller size, close to that occurring at the open gulf stations. Three individual birds showed an intermediate position between the areas inhabited by large size and small size T. gaudichaudii (Fig. 4).

Finally, CDP and SRP samples showed a very close topology (Fig. 4). All the individual birds were grouped in the same section of the 1-2 plane and they were linked with medium-size Themisto gaudichaudii (13 to $17 \mathrm{~mm}$ ). Such sizes were characteristics of some western gulf stations (9 A-B and 10 A-B-C).

\section{DISCUSSION}

The hyperiid amphipod Themisto gaudichaudii is a major component of the macrozooplankton community in Kerguelen waters, occurring with the highest densities in the sheltered Golfe du Morbihan. Seabirds breeding there fed mainly on T. gaudichaudii, thus emphasizing its importance in the upper levels of the local pelagic trophic web. Species of seabirds segregated by preying upon different size classes of the amphipod. To compare the length-frequency distribution of marine organisms in nets and food samples requires that the nets provide an accurate description of food resources accessible to predators (see discussion in Hill et al. 1996). It is well-known and already discussed in the literature that no net samples the water column perfectly, and thus that net samples are subject to bias. In the present study, observations at sea indicate that common diving petrels (CDP) and southern rockhopper penguins (SRP) forage in the immediate vicinity of the breeding colonies (Weimerskirch et al. 1989, authors' unpubl. data). The lengthfrequency distribution of $T$. gaudichaudii at the western gulf stations and in the diet of CDP and SRP presented a strong similarity, both diving species feeding on the largest of the 2 size classes found in nets. Since the ability of ships to catch prey is completely 


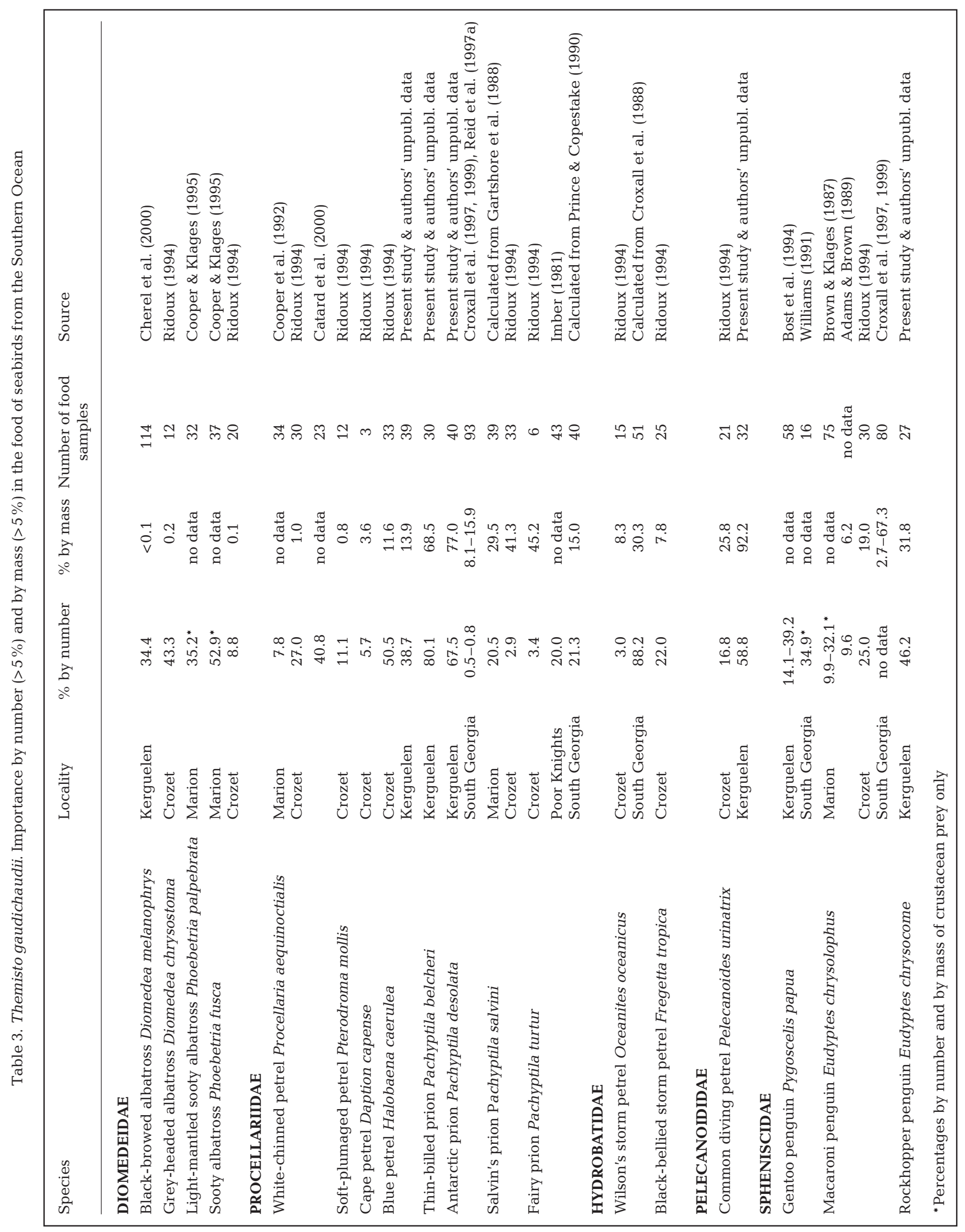


different to that of birds, this similarity strongly suggests that the ORI net sampled accurately the population of $T$. gaudichaudii available to the predators in western gulf stations. The marked difference in the length-frequency distribution of the amphipod at the sampling stations and in the diet of surface-feeding seabirds is thus likely to result from blue petrels (BP), and thin-billed (TBP) and Antarctic prions (AP) foraging outside the study area, in more offshore waters.

\section{Themisto gaudichaudii in Kerguelen waters: comparison with other localities}

Overall, Themisto gaudichaudii was the most abundant species of macrozooplankton collected in Kerguelen waters. Noticeable differences however were found between stations located inside and outside the Golfe du Morbihan. Highest densities and biomasses occurred in the western gulf stations, intermediate values in open gulf stations, and lowest values at the shelf stations. This, together with results from oceanographic cruises performed in more offshore waters (Pakhomov 1993), indicated a decrease in the importance of T. gaudichaudii from coastal to oceanic waters in the vicinity of the Kerguelen archipelago. A decrease abundance of $T$. gaudichaudii from coastal to more offshore waters was also found in South Africa (Siegfried 1965) and around South Georgia (Piatkowski et al. 1994).

In the Golfe du Morbihan, Themisto gaudichaudii are present all year round with the highest abundance occurring during the summer months (Koubbi 1992, Bost et al. 1994). Densities calculated in the present work are in general agreement with those previously reported, but densities from Stn 8 and those from stations sampled in mid-February were consistently higher than the highest values previously found in the area (5 individuals $\mathrm{m}^{-3}$, Bost et al. 1994). Only 2 other important macrozooplanktonic species occur in significant amounts in the Golfe du Morbihan, the copepod Paraeuchaeta antarctica in western gulf waters, and Euphausia vallentini (Koubbi 1992, Bost et al. 1994). This is in marked contrast with the situation prevailing on the Kerguelen shelf and slope, which is characterized by more macrozooplanktonic species, thus generally inducing a lower relative importance of $T$. gaudichaudii by number and by mass within the pelagic community (Pakhomov 1993, Semelkina 1993).

In the Southern Ocean, Themisto gaudichaudii is the most abundant pelagic amphipod, occurring in large numbers in epipelagic waters of the subantarctic and northern Antarctic zones (Kane 1966, Vinogradov et al. 1996). It occurred in most of the net hauls, but densities $>0.1$ individual $\mathrm{m}^{-3}$ (up to 1.5 individuals $\mathrm{m}^{-3}$ ) were rarely reported (Piatkowski 1985, Boden \& Parker 1986, Atkinson \& Peck 1988, Pakhomov \& McQuaid 1996). Densities of T. gaudichaudii in the Golfe du Morbihan are therefore the highest recorded in the Southern Ocean, being similar only to densities found farther north, in upwelling regions of the Benguela area (1.4 to 103.4 individuals $\mathrm{m}^{-3}$, Gibbons et al. 1992). The pelagic ecosystem of the Golfe du Morbihan is simple and very productive: high increases in phytoplankton biomass in spring and summer induce a sharp rise in mesozooplankton production at that time (Razouls et al. 1996, 1997). In turn, a large standing stock of the endemic herbivorous copepod Drepanopus pectinatus supports important populations of the carnivorous T. gaudichaudii and Paraeuchaeta antarctica that then become available for higher predators.

Length-frequency distribution of Themisto gaudichaudii showed different patterns in the 3 groups of stations. No size classes dominated the shelf and open gulf stations (but see Stn 1), while 2 size classes, juveniles and adults with mode at 5 to $6 \mathrm{~mm}$ and 15 to $16 \mathrm{~mm} \mathrm{BL}$, respectively, dominated the western gulf stations in summer. The size of smaller individuals suggests that a significant part consisted of juveniles recently released from the female brood pouch (Kane 1963). Interestingly, only 1 larger size class was found in the Golfe du Morbihan in winter (Bost et al. 1994). This, together with our data, suggests that breeding and the release of the broods take place in spring and early summer, as previously described in oceanic waters (Kane 1966). Sex ratio of T. gaudichaudii was also different among the 3 groups of stations, hence further suggesting that the populations had different characteristics at western and open gulf stations, and at shelf stations.

\section{Themisto gaudichaudii in the diet of Kerguelen seabirds: comparison with other localities}

The present work quantified the importance of Themisto gaudichaudii in the diet of small procellariiforms and penguins during the chick-rearing period at Kerguelen Islands. T. gaudichaudii was a major prey item for the diving SRP and CDP, but not for SGDP. SGDP foraged in offshore Kerguelen waters, where they consistently fed upon the euphausiid Thysanoessa sp. and the copepod Calanoides acutus during the summer months (Bocher et al. 2000a). T. gaudichaudii was also a minor component of the SGDP diet at Crozet (Ridoux 1994) and South Georgia (Reid et al. 1997b), thus emphasizing the trophic segregation between the 2 closely related species of diving petrels breeding there (review in Bocher et al. 2000a). At Kerguelen, T. gaudichaudii is the major prey species of CDP (Bocher 
et al. 2000a, present study), whereas it co-occurred with Euphausia vallentini and the hyperiid Primno macropa as the main items at Crozet Islands (Ridoux 1994), and is less important in South Georgia, where it is replaced by calanoid copepods (Reid et al. 1997b).

The other species of diving birds investigated, the $\mathrm{SRP}$, is known to prey mainly upon crustaceans at nearly all localities (review in Cooper et al. 1990). Our data indicate that fish was also an important component of SRP diet during the crèche stage at Kerguelen Islands; it is moreover the first to record Themisto gaudichaudii as its main crustacean prey, Euphausia vallentini being the major item elsewhere (Brown \& Klages 1987, Ridoux 1994, Hull 1999). Bost et al. (1994), in the only previous detailed food analysis of a seabird breeding in the Golfe du Morbihan, also emphasized the importance of $T$. gaudichaudii (together with $E$. vallentini) in the diet of gentoo penguins Pygoscelis papua foraging there. Like SRP, gentoo penguins breeding at other localities feed on different crustacean species, mainly E. vallentini, and on fish (review in Ridoux 1994).

At the Kerguelen Islands, Themisto gaudichaudii was the main prey of the 3 different species of surfacefeeding seabirds investigated, namely BP and the 2 species of prions. Almost nothing is known about the feeding habits of TBP (Marchant \& Higgins 1990), but analysis of a few food samples from the southern Pacific Ocean (Harper 1972) and the Falkland Islands (Strange 1980) suggested that T. gaudichaudii is a major food item for that species. Quantification of the diet at Kerguelen clearly demonstrated that the amphipod was by far the main prey of TBP both by number $(80 \%)$ and by mass (68\%), a situation that prevailed also for the closely related AP (68 and 77\%, respectively). At South Georgia, where its food and feeding ecology had been detailed, AP feed upon Antarctic krill and copepods, T. gaudichaudii being a less important item (Prince 1980, Croxall et al. 1997, 1999, Reid et al. 1997a). The amphipod was also a major prey of BP at Kerguelen, where it co-occurred with Thysanoessa sp. as the main crustacean items. Elsewhere, BP fed less on fish and more on crustaceans than at Kerguelen, the crustacean diet being dominated by Euphausia superba in South Georgia (Prince 1980), Euphausia vallentini at Marion (Steele \& Klages 1986), and E. vallentini, Thysanoessa sp. and T. gaudichaudii at Crozet Islands (Ridoux 1994).

To summarise, Themisto gaudichaudii was consistently found as a major prey item in the diet of various seabird species (except SGDP) from Kerguelen Islands. There, the amphipod accounted for higher percentages by number and by mass than elsewhere, thus emphasizing its local importance in the nutrition of diving and surface-feeding predators.

\section{Themisto gaudichaudii from food samples and nets: trophic segregation among seabirds}

The present study highlights a dietary segregation among seabirds through predation upon different size classes of Themisto gaudichaudii. In terms of ability to exploit T. gaudichaudii in the water column and their potential foraging range, the CDP and SRP (diving species), and the prions and BP (surface-feeding species) form 2 rather distinct groups. Both CDP and SRP are able to catch prey at depths (Bocher et al. 2000b, Tremblay \& Cherel 2000), and they are commonly observed feeding in the vicinity of the colonies during the daylight hours (authors' unpubl. data). On the other hand, prions and BP forage at the sea surface (Chastel \& Bried 1996), are rarely seen foraging in the Golfe du Morbihan (authors' unpubl. data), and they have the ability to perform trips of long duration far away from the colonies during the chick-rearing period (Chaurand \& Weimerskirch 1994, Weimerskirch et al. 1999, Duriez et al. 2000).

The 2 diving species fed on 1 size class of Themisto gaudichaudii only, as indicated by the pooled results from all the food samples. Comparison of the lengthdistribution of $T$. gaudichaudii in macrozooplankton and food samples showed that both CDP and SRP preyed upon the larger of the 2 size classes occurring in the western gulf. Our data suggest that birds either selected the larger size class in the water column or fed in areas where only this class occurred (like Stn 10). Visual observations support the former hypothesis, because CDP and SRP are rarely seen foraging at the 2 extremities of the Golfe du Morbihan (Stns 8 and 10). In the same way, macaroni penguins Eudyptes chrysolophus are known to select larger, nutritionally superior, mature females of Antarctic krill, small individuals being absent from their stomach contents (Hill et al. 1996). Correspondence analysis showed almost no variation among the CDP and SRP samples, thus indicating little interindividual differences in the food and feeding ecology within the 2 species and within individual birds of each species. While they have different diving abilities (Bocher et al. 2000b, Tremblay \& Cherel 2000), CDP and SRP did not therefore segregate by feeding on different size classes of $T$. gaudichaudii, the 2 populations foraging consistently in the close vicinity of the breeding colonies in the Golfe du Morbihan.

Prions and BP segregated from the 2 diving species by preying upon both juveniles and adults of Themisto gaudichaudii. They moreover segregated themselves by the proportion of juveniles and adults in their diet, BP feeding equally on the 2 size classes, TBP more on juveniles and AP more on adults. The presence of $T$. gaudichaudii in the diet of surface-feeding seabirds is 
easily explained by its regular occurrence at the sea surface (Kane 1966, Pakhomov \& McQuaid 1996). Comparison of the length-distribution of T. gaudichaudii in macrozooplankton and food samples showed that the 3 species fed mainly on different size classes than those found at stations located either within or outside the Golfe du Morbihan. This indicated that prions and BP foraged in more offshore waters, an hypothesis that is in agreement with ship-based census showing that they are found from the Subtropical Front south to the pack-ice in summer in the southern Indian Ocean (Stahl et al. in press). Correspondence analysis of individual food samples reinforced the indication that $\mathrm{BP}$, TBP and AP fed outside the study area, with large variations among individuals in the size of $T$. gaudichaudii eaten. The analysis does not preclude that a few TBP and AP individuals foraged on the smaller size class of T. gaudichaudii in the Golfe du Morbihan, but it clearly indicated that most juveniles and almost all adult amphipods were caught outside the study area. Where prions and BP foraged in offshore waters is not precisely known, but most birds observed feeding were located over neritic and slope waters surrounding the archipelago, and in the oceanic zone south to the Antarctic Continent (Stahl et al. in press).

A main segregation was found in the present study between diving and surface-feeding birds, indicating that both foraging techniques and foraging ranges influenced the characteristics of Themisto gaudichaudii in seabird diets. The short-ranging CDP and SRP fed on adult amphipods in the Golfe du Morbihan, whereas the long-ranging BP, TBP and AP fed on juveniles and adults mostly outside the study area. The sexratio of adult amphipods is in general agreement with this pattern, with values found in CDP and SRP samples (but not in prion and BP samples) in the same range than those of macrozooplankton samples from the western gulf.

\section{Themisto gaudichaudii: a key species in the sub- antarctic pelagic trophic web}

Themisto gaudichaudii occurs in the diet of almost all seabirds from the Southern Ocean. Its importance varies greatly however, depending on the species, locality and years of investigation. Despite its occurrence in significant numbers in the water column (Boden 1985, Piatkowski 1985, Atkinson \& Peck 1988), T. gaudichaudii is generally a minor prey for predators along the Antarctic Continent, Antarctic Peninsula and at South Georgia, due to the overwhelming importance of Antarctic krill there. A few specialized seabirds nevertheless prey on T. gaudichaudii, such as fairy prions Pachyptila turtur and Wilson's storm petrels Oceanites oceanicus at South Georgia (Croxall et al. 1988, Prince \& Copestake 1990). On years of poor Antarctic krill availability however, some predators, including fish (Barrera-Oro et al. 1998), shift to an amphipod diet, and T. gaudichaudii becomes the main prey of macaroni penguins (Croxall et al. 1999), and a major food item of AP (Reid et al. 1997a).

Further north where Antarctic krill does not occur, seabirds feed on other pelagic crustaceans including mainly Themisto gaudichaudii and the subantarctic krill Euphausia vallentini. The latter species generally predominates (Ridoux 1989, 1994, Cooper \& Brown 1990), but the amphipod accounts for a significant part of the diet of both diving and surface-feeding seabirds (Table 3). At subantarctic islands, T. gaudichaudii accounts for a high proportion by number in the food of some albatrosses and large petrels, but, owing to its small size when compared to that of fish and cephalopods, it comprises a negligible percentage by mass of their diet. More noticeable is the importance of T. gaudichaudii in the food of macaroni penguins (Brown \& Klages 1987, Ridoux 1994). In terms of biomass it is one of the predominant species among the seabird community at Marion and Crozet Islands (Adams \& Brown 1989, Guinet et al. 1996). There, T. gaudichaudii is also a major prey of small species of petrels, including BP, Salvin's Pachyptila salvini and fairy prions, and CDP. When comparing localities, however, T. gaudichaudii seems more important in the diet of seabirds at Kerguelen than at any other location (Table 3). Much work however is needed on the food and feeding ecology of predators which breed on the archipelago, because the diet of many important species, including the macaroni penguin, is still largely unknown.

Themisto gaudichaudii in the Southern Ocean was found to be an important prey, not only for seabirds, but also for other marine predators. It was reported as a prey of almost all the baleen whale species, but occurred in significant amounts in stomach contents of sei whales Balaenoptera borealis only (Budylenko 1978). Neritic fish, including various species of nototheniids and the mackerel icefish Champsocephalus gunnari, feed on T. gaudichaudii (Duhamel 1987, Kock et al. 1994, Barrera-Oro et al. 1998), and it is an important prey item for oceanic myctophids (Pakhomov et al. 1996, Kozlov 1995). Among the little information available on the diet of squid, $T$. gaudichaudii is a major food component for the ommastrephids Illex argentinus and Martialia hyadesi (Rodhouse et al. 1992, Ivanovic \& Brunetti 1994, Ivanovic et al. 1998). In turn, these fish and squid form the staple food of higher predators (Sabourenkov 1992, Cherel \& Klages 1998), thus emphasizing the central role of T. gaudichaudii in the pelagic trophic web of the Southern Ocean. 
The main result of this study was to establish that the hyperiid Themisto gaudichaudii is an important local component of the macrozooplankton community and the main prey for planktivorous seabirds inhabiting the subantarctic zone. In certain areas, it therefore has a trophic role similar to that of Antarctic krill Euphausia superba further south (Croxall \& Prince 1980, Miller \& Hampton 1989, Ainley \& DeMaster 1990, Smith \& Schnack-Schiel 1990). T. gaudichaudii is a non-selective, opportunistic carnivore, generally feeding on the most abundant mesozooplankton species (Siegfried 1965, Pakhomov \& Perissinotto 1996, Froneman et al. 2000). Thus, it constitutes an important ecological link between small zooplankton and top consumers, and may effectively control the mesozooplankton standing stock (Pakhomov \& Perissinotto 1996). Our data furthermore suggest that the population dynamics of predators such as penguins and small procellariiform seabirds could be affected in periods of decreased availability of $T$. gaudichaudii, because it constitutes the major part of their diet during the critically important chick-rearing period.

Acknowledgements. The authors thank C. Trouvé and S. Sabini for their help in analysis of dietary samples and zooplankton samples, respectively, and F. Alonzo, G. Fradet, N. Gasco, L. Guérin, F. Jiguet, B. Labidoire, G. Roudaut and the crew of the research vessel 'La Curieuse' for their work in the field. Analysis of the data was supported financially by a grant des Conseils Généraux des Deux-Sèvres et de la Charente Maritime, and by a grant from the Groupement de Recherche en Environnement 1069 'Ecosystèmes Polaires et Anthropisation' from the C.N.R.S. (Programme IOZ: Interactions Oiseaux-Zooplancton). Field work was supported financially and logistically by the Institut Français pour la Recherche et la Technologie Polaires (IFRTP, Programmes No. 109 and 166), and the Terres Australes et Antarctiques Françaises.

\section{LITERATURE CITED}

Adams NJ, Brown CR (1989) Dietary differentiation and trophic relationships in the sub-Antarctic penguin community at Marion Island. Mar Ecol Prog Ser 57:249-258

Ainley DG, DeMaster DP (1990) The upper trophic levels in polar marine ecosystems. In: Smith WO (ed) Polar Oceanography, Part B. Academic Press, San Diego, p 599-630

Atkinson A, Peck JM (1988) A summer-winter comparison of zooplankton in the oceanic area around South Georgia. Polar Biol 8:463-473

Badia J, Do-Chi T (1976) Etude de la cinétique de la structure des populations de Squilla mantis (Crustacea: Stomatopoda) par l'analyse factorielle des correspondances. Mar Biol 36:159-169

Barrera-Oro E, Casaux R, Marschoff E (1998) Analysis of the diet of Champsocephalus gunnari at South Georgia in late summer from 1994 to 1997, Dr Eduardo and L. Holmberg surveys. Committee for the Conservation of Antarctic Marine Living Resources (CCAMLR) Sci 5:103-123

Benzecri JP (1973) L'analyse des données. Tome II-L'analyse des correspondances. Dunod, Paris
Bocher P, Cherel Y, Hobson KA (2000a) Complete trophic segregation between South Georgian and common diving petrels during breeding at Iles Kerguelen. Mar Ecol Prog Ser 208:249-264

Bocher P, Labidoire B, Cherel Y (2000b) Maximum dive depths of common diving petrels (Pelecanoides urinatrix) during the annual cycle at Mayes Island, Kerguelen. J Zool (Lond) 251:517-524

Boden BP (1985) The South African SIBEX I Cruise to the Prydz Bay region, 1984: VIII. The plankton encountered during the survey. S Afr J Antarct Res 15:28-32

Boden BP, Parker LD (1986) The plankton of the Prince Edward Islands. Polar Biol 5:81-93

Bost CA, Koubbi P, Genevois F, Ruchon L, Ridoux V (1994) Gentoo penguin Pygoscelis papua diet as an indicator of planktonic availability in the Kerguelen Islands. Polar Biol 14:147-153

Brown CR, Klages NT (1987) Seasonal and annual variation in diets of macaroni (Eudyptes chrysolophus) and southern rockhopper (E. chrysocome chrysocome) penguins at subAntarctic Marion Island. J Zool (Lond) 212:7-28

Budylenko GA (1978) On sei whale feeding in the Southern Ocean. Rep Int Whal Comm 28:379-385

Catard A, Weimerskirch H, Cherel Y (2000) Exploitation of distant Antarctic waters and close shelf-break waters by white-chinned petrels rearing chicks. Mar Ecol Prog Ser 194:249-261

Chastel O, Bried J (1996) Diving ability of blue petrels and thin-billed prions. Condor 98:627-629

Chaurand T, Weimerskirch H (1994) The regular alternation of short and long foraging trips in the blue petrel Halobaena caerulea: a previously undescribed strategy of food provisioning in a pelagic seabird. J Anim Ecol 63:275-282

Cherel Y, Klages N (1998) A review of the food of albatrosses. In: Robertson G, Gales R (eds) Albatross biology and conservation. Surrey Beatty \& Sons, Chipping Norton, p 113-136

Cherel Y, Weimerskirch H, Trouvé C (2000) Food and feeding ecology of the neritic-slope forager black-browed albatross and its relationships with commercial fisheries in Kerguelen waters. Mar Ecol Prog Ser 207:183-199

Cooper J, Brown CR (1990) Ornithological research at the sub-Antarctic Prince Edward Islands: a review of achievements. S Afr J Antarct Res 20:40-57

Cooper J, Brown CR, Gales RP, Hindell MA, Klages NTW, Moors PJ, Pemberton D, Ridoux V, Thompson KR, Van Heezik YM (1990) In: Davis LS, Darby JT (eds) Penguin biology. Academic Press, San Diego, p 131-156

Cooper J, Fourie A, Klages NTW (1992) The diet of the whitechinned petrel Procellaria aequinoctialis at subAntarctic Marion Island. Mar Ornithol 20:17-24

Cooper J, Klages NTW (1995) The diets and dietary segregation of sooty albatrosses (Phoebetria spp.) at subantarctic Marion Island. Antarct Sci 7:15-23

Croxall JP, Prince PA (1980) Food, feeding ecology and ecological segregation of seabirds at South Georgia. Biol J Lin Soc 14:103-131

Croxall JP, Hill HJ, Lidstone-Scott R, O'Connel MJ, Prince PA (1988) Food and feeding ecology of Wilson's storm petrel Oceanites oceanicus at South Georgia. J Zool (Lond) 216: 83-102

Croxall JP, Prince PA, Reid K (1997) Dietary segregation of krill-eating South Georgia seabirds. J Zool (Lond) 242: $531-556$

Croxall JP, Reid K, Prince PA (1999) Diet, provisioning and productivity responses of marine predators to differences in availability of Antarctic krill. Mar Ecol Prog Ser 177: 115-131 
de Broyer C, Jazdzewski K (1993) Contribution to the marine biodiversity inventory. A checklist of the Amphipoda (Crustacea) of the Southern Ocean. Inst R Sci Nat Belg Doc Trav 73:1-154

Duhamel G (1987) Ichtyofaune des secteurs indien occidental et atlantique oriental de l'Océan Austral: biogéographie, cycles biologiques et dynamique des populations. Unpubl. thesis, Université de Paris VI

Duriez O, Weimerskirch H, Fritz H (2000) Regulation of chick provisioning in the thin-billed prion: an interannual comparison and manipulation of parents. Can J Zool 78: $1275-1283$

Everson I, Ward P (1980) Aspects of Scotia Sea zooplankton. Biol J Lin Soc 14:93-101

Falla RA (1937) Birds. Rep British and New Zealand Antarct Res Exp 1929-31 2B:1-304

Froneman PW, Pakhomov EA, Treasure A (2000) Trophic importance of the hyperiid amphipod, Themisto gaudichaudii, in the Prince Edward Archipelago (Southern Ocean) ecosystem. Polar Biol 23:429-436

Gales RP (1987) Validation of the stomach-flushing technique for obtaining stomach contents of penguins. Ibis 129: 335-343

Gartshore NA, Steele WK, Klages NT (1988) Summer diet of the Salvin's prion at sub-Antarctic Marion Island. S Afr J Zool (23) 4:309-313

Gibbons MJ, Stuart V, Verheye HM (1992) Trophic ecology of carnivorous zooplankton in the Benguela. S Afr J Mar Sci $12: 421-437$

Gower JC (1987) Introduction to ordination techniques. In: Legendre P, Legendre L (eds) Developments in numerical ecology. NATO ASI Series G Ecol Sci 14:3-64

Gray JS, McHardy RA (1967) Swarming of hyperiid amphipods. Nature 215:100

Guinet C, Cherel Y, Ridoux V, Jouventin P (1996) Consumption of marine resources by seabirds and seals in Crozet and Kerguelen waters: changes in relation to consumer biomass 1962-85. Antarct Sci 8:23-30

Harper PC (1972) The field identification and distribution of the thin-billed prion (Pachyptila belcheri) and the Antarctic prion (Pachyptila desolata). Notornis 19:140-175

Hill HJ, Trathan PN, Croxall JP, Watkins JL (1996) A comparison of Antarctic krill Euphausia superba caught by nets and taken by macaroni penguins Eudyptes chrysolophus: evidence for selection? Mar Ecol Prog Ser 140:1-11

Hull CL (1999) Comparison of the diets of breeding royal (Eudyptes schlegeli) and rockhopper (Eudyptes chrysocome) penguins on Macquarie Island over three years. J Zool (Lond) 247:507-529

Imber MJ (1981) Diets of stormpetrels Pelagodroma and Garrodia and of prions Pachyptila (Procellariiformes). In: Cooper J (ed) Proceedings of the symposium on birds of the sea and shore. African Seabird Group, Cape Town, p 63-88

Ivanovic ML, Brunetti NE (1994) Food and feeding of Illex argentinus. Antarct Sci 6:185-193

Ivanovic ML, Brunetti NE, Elena B, Rossi GR (1998) A contribution to the biology of the ommastrephid squid Martialia hyadesi (Rochebrune and Mabille, 1889) from the SouthWest Atlantic. S Afr J Mar Sci 20:73-79

Kane JE (1963) Stages in the early development of Parathemisto gaudichaudii (Guér.) (Crustacea Amphipoda: Hyperiidea), the development of secondary sexual characters and of the ovary. Trans R Soc NZ Zool 3:35-46

Kane JE (1966) The distribution of Parathemisto gaudichaudii (Guér.), with observations on its life-history in the $0^{\circ}$ to $20^{\circ}$ E sector of the Southern Ocean. Discov Rep 34: $163-198$
Kock KH, Wilhelms S, Everson I, Gröger J (1994) Variations in the diet composition and feeding intensity of mackerel icefish Champsocephalus gunnari at South Georgia (Antarctic). Mar Ecol Prog Ser 108:43-57

Koubbi P (1992) L'ichtyoplancton de la partie indienne de la province kerguelenienne (bassin de Crozet et plateau de Kerguelen): identification, distribution spatio-temporelle et stratégies de développement larvaire. PhD thesis, Université de Paris VI

Kozlov AN (1995) A review of the trophic role of mesopelagic fish of the family Myctophidae in the Southern Ocean ecosystem. Committee for the Conservation of Antarctic Marine Living Resources (CCAMLR) Sci 2:71-77

Marchant S, Higgins PJ (1990) Handbook of Australian, New Zealand and Antarctic birds. Vol. 1. Oxford University Press, Melbourne

Miller DGM, Hampton I (1989) Biology and ecology of the Antarctic krill (Euphausia superba Dana): a review. Biological Investigations of Marine Antarctic Systems and Stock Sci Ser 9:1-166

Omori M, Ikeda T (1984) Methods in marine zooplankton ecology. J Wiley \& Sons, New York

Pakhomov EA (1993) Macroplankton of the waters contiguous to the Kerguelen Archipelago. In: Duhamel G (ed) Campagnes SKALP 1987 et 1988 aux îles Kerguelen à bord des navires 'SKIF' et 'KALPER'. Institut Français pour la recherche et la technologie polaires, les rapports des campagnes à la mer 93-01:104-112

Pakhomov EA, McQuaid CD (1996) Distribution of surface zooplankton and seabirds across the Southern Ocean. Polar Biol 16:271-286

Pakhomov EA, Perissinotto R (1996) Trophodynamics of the hyperiid amphipod Themisto gaudichaudii in the South Georgia region during late austral summer. Mar Ecol Prog Ser 134:91-100

Pakhomov EA, Perissinotto R, McQuaid CD (1996) Prey composition and daily rations of myctophid fishes in the Southern Ocean. Mar Ecol Prog Ser 134:1-14

Park YH, Gambéroni L (1997) Cross-frontal exchange of Antarctic intermediate water and Antarctic bottom water in the Crozet Basin. Deep-Sea Res II 44:963-986

Paulian P (1953) Pinnipèdes, cétacés, oiseaux des Iles Kerguelen et Amsterdam. Mission Kerguelen 1951. Mém Inst Rech Sci Madag Ser A Biol Anim 8:111-234

Piatkowski U (1985) Distribution, abundance and diurnal migration of macrozooplankton in Antarctic surface waters. Meeresforsch 30:264-279

Piatkowski U, Rodhouse PG, White MG, Bone DG, Symon C (1994) Nekton community of the Scotia Sea as sampled by the RMT 25 during austral summer. Mar Ecol Prog Ser 112:13-28

Prince PA (1980) The food and feeding ecology of blue petrel (Halobaena caerulea) and dove prion (Pachyptila desolata). J Zool (Lond) 190:59-76

Prince PA, Copestake PG (1990) Diet and aspects of fairy prions breeding at South Georgia. Notornis 37:59-69

Razouls S, Koubbi P, Mayzaud P (1996) Spatio-temporal distribution of mesozooplankton in a sub-Antarctic coastal basin of the Kerguelen Archipelago (southern Indian Ocean). Polar Biol 16:581-587

Razouls S, de Bovée F, Delille D, Fiala M, Mayzaud P (1997) Temporal variability of bacteria, phytoplankton and zooplankton assemblages of the sub-Antarctic Morbihan Bay (Kerguelen Archipelago). In: Battaglia B, Valencia J, Walton DWH (eds) Antarctic communities: species, structure and survival. Cambridge University Press, Cambridge, p 86-92 
Reid K, Croxall JP, Edwards TM (1997a) Interannual variation in the diet of the Antarctic prion Pachyptila desolata at South Georgia. Emu 97:126-132

Reid K, Croxall JP, Edwards TM, Hill HJ, Prince PA (1997b) Diet and feeding ecology of the diving petrels Pelecanoides georgicus and P. urinatrix at South Georgia. Polar Biol 17:17-24

Ridoux V (1989) Impact des oiseaux de mer sur les ressources marines autour des Iles Crozet: estimation préliminaire. In: Actes du colloque sur la recherche Française dans les Terres Australes, Strasbourg 1987. Comité Nat Fr Rech Antarct, p 85-94

Ridoux V (1994) The diets and dietary segregation of seabirds at the subantarctic Crozet Islands. Mar Ornithol 22:1-192

Rodhouse PG, White MG, Jones MRR (1992) Trophic relations of the cephalopod Martialia hyadesi (Teuthoidea: Ommastrephidae) at the Antarctic Polar Front, Scotia Sea. Mar Biol 114:415-421

Sabourenkov E (1992) Myctophids in the diet of Antarctic predators. Sel Sci Pap Sci Committee for the Conservation of Antarctic Marine Living Resources (CCAMLR) Sci 1991: 335-368

Semelkina AN (1993) Development of the zooplankton in the Kerguelen Islands region in the years 1987-88. In: Duhamel G (ed) Campagnes SKALP 1987 et 1988 aux îles Kerguelen à bord des navires 'SKIF' et 'KALPER'. Institut Français pour la recherche et la technologie polaires, les rapports des campagnes à la mer 93-01: 90-103

Editorial responsibility: Otto Kinne (Editor), Oldendorf/Luhe, Germany
Siegfried WR (1965) Observations on the amphipod Parathemisto gaudichaudi (Guer.) off the west coast of South Africa. Zool Afr 1:339-352

Smith SL, Schnack-Schiel SB (1990) Polar zooplankton. In: Smith WO (ed) Polar oceanography. Part B. Academic Press, San Diego, p 527-598

Stahl JC, Bartle JA, Jouventin P, Roux JP, Weimerskirch H (in press) Atlas of seabird distribution in the south-west Indian Ocean. Mar Ornithol

Steele WK, Klages NT (1986) Diet of the blue petrel at subAntarctic Marion Island. S Afr J Zool 21:253-256

Strange IJ (1980) The thin-billed prion, Pachyptila belcheri, at New Island, Falkland Islands. Gerfaut 70:411-445

Tremblay Y, Cherel Y (2000) Benthic and pelagic dives: a new foraging behaviour in rockhopper penguins. Mar Ecol Prog Ser 204:257-267

Vinogradov ME, Volkov AF, Semenova TN (1996) Hyperiid amphipods (Amphipoda, Hyperiidea) of the world oceans. Science Publishers, Lebanon

Weimerskirch H, Fradet G, Cherel Y (1999) Natural and experimental changes in chick provisioning in a longlived seabird, the Antarctic prion. J Avian Biol 30:165-174

Weimerskirch H, Zotier R, Jouventin P (1989) The avifauna of the Kerguelen Islands. Emu 89:15-29

Wilkinson L (1999) SYSTAT 9 for Windows. SPSS, Chicago

Williams TD (1991) Foraging ecology and diet of gentoo penguins Pygoscelis papua at South Georgia during winter and an assessment of their winter prey consumption. Ibis $133: 3-13$

Submitted: November 23, 2000, Accepted: July 24, 2001

Proofs received from author(s): November 5, 2001 